\title{
Representación fílmica del Derecho del Trabajo durante el Franquismo ${ }^{1}$ \\ Filmic representation of Labour Law during the Franco Regime
}

\author{
Juan ESCRIBANO GUTIÉRREZ \\ Profesor Titular de Derecho del Trabajo \\ Departamento de Derecho. Facultad de Derecho \\ Universidad de Almería \\ jescriba@ual.es
}

Para mi abuelo Juan, campesino sin tierra en la España del franquismo

Recibido: 3 de diciembre de 2015

Aceptado: 13 de mayo de 2016

\section{RESUMEN}

El mundo del trabajo no ha gozado de una amplia representación a lo largo de la historia del cine. No obstante, un análisis de los films que han tratado directa o indirectamente dicha temática durante un período histórico determinado puede contribuir a arrojar importantes conclusiones sobre la manera en que se hizo frente social y jurídicamente a esta importante actividad humana. En concreto, el análisis del cine durante el franquismo nos posibilita contemplar aspectos tan importantes como la incorporación de la mujer al mundo del trabajo, la represión del hecho sindical o la crisis de empleo en el primer franquismo.

PALABRAS CLAVE: Trabajo, historia, franquismo, imagen, proletario, Falange, Transición.

\begin{abstract}
The world of labour has not had a wide representation along the history of cinema. Nevertheless, an analysis of the films that have dealt with that subject direct or indirectly during a certain historical period can help to throw important conclusions about the ways in wich this important human activity was socially and juridically faced. Specifically, the analysis of the cinema production during Franco's regime makes us possible to contemplate such important aspects as the incorporation of women to the work forces, the unions backlash or the crisis of employment in the first period of Franco's regime.
\end{abstract}

KEYWORDS: Labour, history, proletariat, image, Falange, Franco regime, transition to democracy.

\section{RÉSUMÉ}

Le monde du travail n'a pas bénéficié d'une large représentation dans l'histoire du cinéma. Cependant, une analyse des films qui ont directement ou indirectement abordé cette question au cours

${ }^{1}$ Este estudio es fruto de un proyecto I+D dirigido por el prof. Dr. Federico Fernández-Crehuet López, financiado con cargo al Plan Nacional de Investigación, convocatoria 2014, con el título «Tradición y Constitución: Problemas constituyentes de la España Constitucional»(DER201456291-C3-3-P). 
d'une période historique particulière peut aider à montrer quelques conclusions importantes sur la façon dont social et juridiquement cette importante activité humaine a été confrontée. Plus précisément, l'analyse du film au cours du régime de Franco nous permet d'envisager des aspects importants tels que l'intégration des femmes dans le travail, la répression des syndicats ou la crise de l'emploi au début du période franquiste.

MOTS CLÉ: Travail, histoire, Franco, image, prolétariat, Falange, Transition.

SUMARIO: 1. Algunos apuntes sobre derecho del trabajo y cine durante el franquismo. 2. Periodización de la representación del mundo del trabajo en el cine del franquismo. 2.1. El periodo autárquico: 2.2 El continuismo del franquismo. Aparición de las primeras fracturas. A. El desencanto de Falange. B. El comienzo de la disidencia. 2.3. El nuevo cine español y la representación fílmica del trabajo. 2.4. El trabajo en el landismo. 2.5. Hacia el final del largo túnel: tardofranquismo y transición.

\section{Algunos apuntes sobre derecho del trabajo y cine durante el franquismo}

El cambio de régimen de la República a la dictadura no supuso una alteración significativa de la regulación de las condiciones de trabajo en nuestro país. De este modo, la Ley de Contrato de Trabajo de 1944 (LCT) supuso la recuperación de buena parte de los elementos ya recogidos en la Ley de Contrato de Trabajo de 1931. De una comparación entre ambos textos desprende una significativa semejanza en los aspectos relacionados con la prestación individual de trabajo, distanciándose, en cambio, significativamente, en la vertiente colectiva.

El texto de 1944 excluye a los pactos colectivos de los instrumentos de regulación de las condiciones de trabajo, ocupando ese espacio la intervención directa del Estado (arts. 3 y 9). Del mismo modo, el Fuero del Trabajo de 1938, en su título XI, calificó a los actos individuales o colectivos que de algún modo turbaran la normalidad de la producción o atentaran contra ella, como delitos de lesa patria. No obstante, cuando los conflictos colectivos eran evidentes, se aprueba la Ley de 24 de abril de 1958, por la que se admitían los convenios colectivos de trabajo, eso sí, atribuyendo su legitimidad a los órganos de representación monopolizados por la estructura sindical del régimen.

Partiendo de estas premisas, la regulación franquista del trabajo se mantendrá inalterada en sus aspectos más reseñables, incorporándose únicamente modificaciones parciales. De hecho, la LCT no se derogaría hasta la entrada en vigor del Estatuto de los Trabajadores de 1980 (Disposición Final Tercera) y, aún así, algunos de sus elementos pasarán al nuevo texto. La fuerte jerarquía empresarial, definida en el Título VIII del Fuero del Trabajo, tiene su manifestación más significativa en la creación de una peculiar fuente de regulación de las condiciones de trabajo de origen unilateral empresarial: los reglamentos de régimen interior (Decreto de 12 de enero de 1961). Los espacios no ocupados como consecuencia de la inexistencia de negociación colectiva serán ocupados por las Reglamentaciones de Trabajo y las Ordenanzas Laborales.

Una clara seña de identidad de la regulación del trabajo durante el franquismo lo constituirá el tipo de regulación referida al trabajo de la mujer, aunque también 
aquí el régimen demuestra capacidad de cambio. La mujer, según el art. 58 LCT, ni tan siquiera tenía derecho al cobro de su salario, pudiendo ocupar la posición de acreedor de éste el marido. Más tarde, el Fuero de los Españoles (1945) ya vino a mantener en sus arts. 11 y 24 la igualdad de todos los españoles para ejercer su derecho al trabajo. Esta declaración formal tiene su desarrollo en la Ley de 24 de julio de 1961, donde se reconoce el derecho de la mujer a desempeñar todos aquellos trabajos que no fueran en contra de como era entendida entonces su condición de mujer (magistratura, ejército, etc.), si bien podía exigirse el beneplácito del marido en aquellos casos en que la mujer estuviera casada.

En definitiva, el régimen franquista, desde la perspectiva de la regulación laboral, se caracteriza por un mantenimiento de ciertos principios inalterados, si bien, en muchos aspectos, manifiesta una significativa capacidad de adaptación, lo que le permite, sin duda, seguir existiendo a pesar de las claras diferencias de la España de los 40 y la de finales de los 60.

Por lo que se refiere al reflejo cinematográfico de esta larga y lenta evolución de las características del trabajo y su regulación, la nota más reseñable será la escasa atención merecida, en general, por esta temática. Sólo sectores marginados de la gran industria del cine español se empeñan en configurar un cine alejado de los patrones más típicos de la «españolada». La década de los 40 , dentro de sus limitaciones industriales, no creará un cine social fiel a los principios que tan prosopopéyicamente consagran los diferentes cuerpos normativos y los textos fundadores de los principios de Falange. No obstante, las escasas muestras de este tipo de cine sirven como barómetro del grado de frustración ante el incumplimiento de las expectativas puestas en la contienda civil. Los cincuenta, al tiempo que el cine de niños cantores y de milagros hacia furor, conoce la eclosión de un cine de gran calidad técnica y argumental inspirado en el neorrealismo italiano. La consecuencia será el cine del «miserabilismo», un tanto pesimista y en absoluto ensalzador, tampoco ahora, de los valores que el Fuero del Trabajo atribuyó al trabajo humano.

Sin prácticamente haber nacido, la década de los 60 vive el entierro de un cine social riguroso y nos ofrece la representación fílmica de las frustraciones de una generación procedente de las clases medias y que no está especialmente sensibilizada con los problemas del trabajo. El franquismo, también en lo referente al cine, manifiesta una gran capacidad de adaptación, y permite, dentro de los límites impuestos por la censura, la existencia de un núcleo, si bien pequeño, de cine disidente.

Ésta será, en definitiva, la nota característica del resto de la época analizada y que se extenderá, salvo escasas excepciones, hasta el momento actual, no terminando el cine español de generar ejemplos como los de un cierto cine social británico o francés ${ }^{2}$.

\footnotetext{
${ }^{2}$ Sobre este aspecto, véase más ampliamente M.M. Ruiz Castillo y J. Escribano Gutiérrez, $E l$ derecho de huelga y el cine, Valencia, Tirant lo Blanch, 2007, pp. 13-21.
} 


\section{Periodización de la representación del mundo del trabajo en el cine del franquismo}

\subsection{El periodo autárquico}

Tras el golpe de estado de 18 de julio de 1936, la alianza de fuerzas vencedoras tratará de crear las bases de un nuevo Estado que niega la mayoría de los logros del régimen republicano. En lo que respecta a nuestro objeto de estudio, el Fuero del Trabajo, promulgado el año 1938, configura los elementos determinantes del tratamiento del trabajo por cuenta ajena durante un largo periodo de tiempo. Básicamente, supuso declarar fuera de la ley a las organizaciones sindicales opuestas al levantamiento militar, decretando su disolución y la incautación de sus bienes $^{3}$. Junto a ello, concedió al Estado la facultad exclusiva de regular las condiciones de trabajo, sin dejar espacio alguno a la negociación colectiva ${ }^{4}$; y prohibió las asociaciones «creadas para defender o representar total o parcialmente intereses económicos de clase», admitiéndose exclusivamente la organización sindical de FET de las JONS a través de la Ley de Unidad Sindical de 26 de noviembre de 1940. Por último, consideró delito «los actos individuales y colectivos que de algún modo turben la normalidad de la producción» ${ }^{6}$, considerando delictivas las «huelgas de obreros» ${ }^{7}$.

Al mismo tiempo, diseñaba un proyecto nacionalsindicalista de Estado, tal y como el Fuero del Trabajo afirmaba solemnemente:

«Renovando la tradición católica, de justicia social y alto sentido humano que informó nuestra legislación del Imperio, el Estadio Nacional en cuanto es instrumento totalitario al servicio de la integridad patria, y Sindicalista en cuanto representa una reacción contra el capitalismo liberal y el materialismo marxista, emprende la tarea de realizar con aire militar, constructivo y gravemente religioso la Revolución que España tiene pendiente y que ha de devolver a los españoles, de una vez para siempre, la Patria, el Pan y la Justicia».

En lo que respecta al trabajo individual, la transposición de estos principios implicó una alta consideración del mismo, pudiéndose resumir sus caracteres en los siguientes ${ }^{8}$ :

a) Se vincula el trabajo a las más elevadas cualidades del hombre, confiriendo a quien lo presta una dignidad mayor, y provocando con ello la correspondiente obligación del Estado de facilitar su desarrollo.

\footnotetext{
${ }^{3}$ Decreto de 13 de septiembre de 1936 y Orden de 10 de enero de 1937.

${ }^{4}$ Fuero del Trabajo de 1938, Declaración III,4.

${ }_{6}^{5}$ Art. 1 de la Ley de 26 de diciembre de 1940.

${ }^{6}$ Fuero del Trabajo, Declaración XI,1.

${ }^{7}$ Art. 222 del Código Penal de 1944.

${ }^{8}$ Más ampliamente, A.V. Sempere Navarro, Nacionalsindicalismo y relación de trabajo, Akal, Madrid, 1982, p. 72.
} 
b) Se resalta el carácter personal y humano del trabajo. De este carácter personal se deriva la consideración del trabajo como profundamente ennoblecedor.

c) El trabajo fomenta, según estos principios, la armonía social. El trabajo será el que permita la cooperación efectiva de todos los elementos, sectores y categorías profesionales que intervienen en la producción ${ }^{9}$.

d) La alta consideración del trabajo implica un carácter fuertemente heterónomo de la regulación de su prestación y su consagración como un derecho de todos los españoles ${ }^{10}$.

e) El trabajo se configura, por último, no sólo como derecho, sino también como deber: «el derecho de trabajar es consecuencia del deber impuesto al hombre por Dios para el cumplimiento de sus fines individuales y la prosperidad y la grandeza de la Patria» ${ }^{11}$.

En otro orden de cosas, el nuevo Derecho del Trabajo estará presidido por la fuerte reglamentación y control de todos los aspectos colectivos de esta disciplina. El principio armonicista se convertirá en lógico trasunto del ideario de los vencedores. Efectivamente, el franquismo acabó por decreto con la lucha de $\operatorname{clases}^{12}$ y con su lógica consecuencia, las organizaciones sindicales libres, pues tanto empresarios como obreros han de confundirse en el concepto de productores consagrados a una misma tarea. Es por ello por lo que la empresa se concibe como un lugar donde están presentes relaciones de cooperación y no de enfrentamiento ${ }^{13}$, bajo la organización del empresario.

En conclusión, este breve repaso por las notas caracterizadoras del Derecho del Trabajo en el franquismo nos ofrece una disciplina marcada por la fuerte jerarquización empresarial, por la eliminación de toda manifestación de oposición sindical y por el ensalzamiento de los valores morales y sociales del trabajo. Parece lógico pensar que el cine de la década de los cuarenta (o, más exactamente, de entre 1939 y 1951) debiera expresar estos valores, sobre todo teniendo en cuenta la inexistencia, tras la dura represión de posguerra, de un oposición interna mínimamente organizada en un mundo, como es el del cine, bastante exclusivista en general.

Respecto a lo anterior, cabe advertir, en primer lugar, el destacado valor otorgado por el franquismo al cine en una doble dimensión, que en cierto sentido no sólo estará presente en este periodo, sino hasta la misma transición. El cine es concebido como un instrumento ideal para la transmisión de los valores que presiden el Estado, pero, al mismo tiempo, se concibe como una vía de evasión de los espectadores. Es decir, propaganda y diversión deberán ser notas especialmente señaladas en esta época.

\footnotetext{
${ }^{9}$ L. Legaz y Lacambra, Estudios de doctrina judicial y social, Bosch, Barcelona, 1940.

${ }^{10}$ A.V. Sempere Navarro, Nacionalisindicalismo, p. 75.

${ }^{11}$ Declaración I-5 del Fuero del Trabajo.

${ }^{12}$ Decreto de 7 de octubre de 1939.

${ }^{13}$ M. Hernainz Márquez, «La conciliación sindical», Revista de Trabajo, V, 1950, p. 382.
} 
El primero de los aspectos referidos, esto es, la propaganda, requería, por una parte, de la creación de una nueva industria cinematográfica en cuya cabeza estuvieran directores afines al régimen ${ }^{14}$, pero también de mecanismos de control externo a la actividad artística que impidieran la desviación de la ortodoxia franquista. Respecto a este segundo aspecto, la censura cinematográfica se instaura con enorme prontitud. Una Orden de 21 de marzo de 1937 crea la Junta de Censura Cinematográfica con sedes en Sevilla y La Coruña con el objetivo de garantizar que la actividad cinematográfica se desenvolviera dentro de las normas patrióticas, de cultura y moralidad que en el nuevo Estado deben imperar ${ }^{15}$. No obstante, la adscripción ideológica de los directores activos durante este periodo hace innecesaria la censura ${ }^{16}$ al menos en los aspectos que aquí serán tratados ${ }^{17}$. En lo que respecta a las relaciones entre propaganda y el cine, este último era considerado como un excelente medio de transmisión del ideario nacionalsindicalista, de manera que se crea un cine militante que no desaprovecha ninguna oportunidad para servir de correa de transmisión de aquél ${ }^{18}$. Este objetivo se resume claramente, en el aspecto que aquí más interesa, en las siguientes palabras:

España ha de lograr «un cine que supere al de tipo individualístico, capitalista y occidental y, al mismo tiempo, que supere también al cine soviético, de masas absolutas, de subversión social [...], Dios sabe si ello será la gloria de un futuro cine español, creado con genio de España, es decir, con genio universal y catolicista» ${ }^{19}$.

Una vez resumidos los caracteres ideológicos que posee el trabajo en el ideario del franquismo y la presentación del cine como un instrumento muy apropiado de representación del mismo, habremos de comprobar, sobre la base de los ejemplos que nos han llegado, si durante estos primeros años existe una representación fílmica de dichos valores referidos al mundo laboral. En primer lugar, debe recordarse que son escasos, en general, los ejemplos referidos a semejante temática, problema, por otra parte, no específico de este momento histórico ni tampoco del caso español. Aun así, podemos espigar algunas películas que nos posibilitarán dicho objetivo ${ }^{20}$.

\footnotetext{
${ }^{14}$ Sobre los específicos directores claramente adscritos al franquismo, Berthier, Le franquismo et son image. Cinème et propagande, Presses Universitaires, Toulouse, 1998.

${ }^{15}$ R.R. Tranche y V. Sánchez-Biosa, NO-DO. El tiempo y la memoria, Cátedra-Filmoteca Española, Madrid, 2000, p. 184.

16 J.L. Castro de Paz, Un cinema herido. Los turbios años cuarenta en el cine español (19391950), Paidós, Barcelona, 2002, p. 28.

${ }^{17}$ J.M. Company, Formas y perversiones del compromiso. El cine español de los años cuarenta, Valencia, Eutopías/Episteme, 1997, p. 2.

${ }^{18}$ D. Galán, «El cine español de los años cuarenta», en R. Gubern y otros, Un siglo de cine español, Academia de las Artes, Madrid, 1997, p. 125; C. Heredero, «España bajo el franquismo: imágenes parásitas y resistencias crítica», en Monterde y Riambau (coord.), Historia general del cine, vol. IX, Cátedra, Madrid, pp. 183 y ss.

${ }^{19}$ Cita de Ernesto Giménez Caballero en J.E. Monterde, «El cine de la autarquía», en R. Gubern y otros, Historia del cine español, Cátedra, Madrid, 2004, p. 213.

${ }^{20}$ Básicamente, podemos destacar las siguientes películas: La aldea maldita (Florián Rey, 1942); Huella de luz (R. Gil, 1942); Mariona Rebull (Sáenz de Heredia, 1947); Las aguas bajan
} 
El primer hito temático digno de ser resaltado se mantendrá y vivificará en periodos posteriores, y además enlaza con uno de los principios ideológicos del falangismo: la bondad del trabajo directo de la tierra y el retorno al mundo rural. Este deseo del retorno al campo, propio de todas los países del espectro ideológico del español, se ve acrecentado en nuestro caso por el hecho de que fue el campo el sector más fiel a los golpistas, frente a las grandes ciudades, que resistieron durante toda la guerra ${ }^{21}$.

Es el retorno al campo como instrumento de salvación tras un periplo de abyección, consecuencia de la huida de las raíces, el eje temático de La aldea maldita (Florián Rey, 1942). Debe destacarse (cuestión a la que con posterioridad nos referiremos) el diferente tratamiento que esta misma temática tendrá una década más tarde, cuando se transformará en una crítica al primer desarrollismo. En esta película (una versión del clásico mudo del mismo autor de la década de los treinta), Florián Rey describe las dificultades de la vida de unos agricultores que habitan una aldea castellana a la que la suerte le es adversa. La familia protagonista ve su suerte aún empeorada tras el enfrentamiento del padre de familia con el terrateniente del lugar. La huida de aquél precipitará los acontecimientos, provocando, en su ausencia, la caída de la mujer, que marcha a Salamanca a trabajar en un local de mala nota. La única manera de solucionar esta situación pasa necesariamente por la petición de disculpas al terrateniente agredido y la vuelta a la tierra. Este es, en cierto modo, el nudo argumental de El último caballo (Edgar Neville, $1950)^{22}$, donde el caballo simboliza lo que de España se pierde como consecuencia de la industrialización y la urbanización frente al ruralismo. Este filme culmina con el protagonista (interpretado por Fernán-Gómez) gritando contra el materialismo y la motorización. Previamente, se ha constatado lo poco adaptada que está la vida de la ciudad y los empleos en ella existentes a los auténticos intereses de los ciudadanos. Por ello, resultan una salvación los respectivos despidos de los protagonistas, los cuales se asociarán con un pequeño propietario de una finca de Madrid que se niega a vender, a pesar de los pingües beneficios que ello le reportaría, el solar de su propiedad para la construcción de rascacielos. La tierra nunca deja de dar beneficios, aduce como justificación a su actitud.

Sin duda, la más paradigmática representación del falangismo del utópico regreso a la tierra lo constituirá Un hombre va por el camino (Mur Oti, 1949) ${ }^{23}$, donde la tierra simboliza el retorno a los valores más esenciales del ser español según los moldes ideológicos de referencia (tal y como demostraría, desde su punto de vista,

negras (Sáenz de Heredia, 1948); El último caballo (Edgar Neville, 1950); Historia de una escalera (Ignacio F. Iquino, 1950); La honradez de la cerradura (Luis Escobar, 1950).

${ }^{21}$ M., Tuñón de Lara Historia de España, Labor, Barcelona, Tomo 10*, p. 461.

${ }^{22}$ Considerada una nueva avanzadilla del neorrealismo imperante en la siguiente década (D. Galán, «El cine español de los años cuarenta», p. 131.

${ }^{23}$ S. Zunzunegui, «Identificación de un cineasta. Lugar de Manuel Mur Oti en el cine español», en Castro de Paz y Pérez Perucha (coords.), El cine de Manuel Mur Oti, Orense, IV Festival Internacional de Cine Independiente de Ourense, 1999. 
el apoyo del mundo rural a la, por ellos denominada, Cruzada $^{24}$ ), además de unos modos de vida y trabajo más acordes a las necesidades del hombre.

Conforme al principio armonicista, los conflictos entre clases generan distorsión, por lo que sólo a través de la desaparición de éstas se puede alcanzar la paz social necesaria para posibilitar un futuro de progreso del país. Este mismo principio será el que posibilite la promoción social de un modesto oficinista en Huella de luz (R. Gil, 1942). El sueño de alcanzar una vida mejor a la que le ofrece su posición social se ve colmado gracias a la ayuda de su bondadoso jefe, que terminará favoreciendo un enlace matrimonial ventajoso para dicho trabajador. A través de esta obra parece poder constatarse, en cierta medida, una falta de fe en los resultados que puede proporcionar, por sí mismo, el propio trabajo, medidos aquellos sobre todo en términos de mejora de las propias condiciones de vida, así como de promoción social. Se trata ésta, de hecho, de una temática que, si bien aparece de modo aquí un tanto embrionario, obtendrá continuidad posteriormente, lo cual supone de hecho un apartamiento del ideario falangista del trabajo, según el cual este último constituye precisamente un instrumento de dignificación de quien lo ejerce.

Este principio armonicista, como es lógico, no niega la actual existencia de desfavorecidos, pero sí propugna la necesidad de superar las diferencias sociales a través de la identificación en el valor superior del bien de la patria. Para facilitar dicha superación se arbitra un elemento argumental muy repetido en este cine y que se refiere a otro pilar del nuevo régimen: la Iglesia. Efectivamente, el cura, más o menos comprometido, se convierte en figura de unión y propulsor de la necesaria comunidad de intereses presente en el ideario de la Dictadura ${ }^{25}$.

Destacan también en esta primera década de la historia del cine español durante el franquismo las aportaciones de José Luís Sainz de Heredia. Tras la paradigmáticamente franquista Raza, este primo de José Antonio llevará al cine dos adaptaciones de sendas novelas de Ignacio Agustí y Palacio Valdés: Mariona Rebull (1947) y Las aguas bajan negras (1948). Se trata, en ambos casos, de películas que reflejan los conflictos socio-laborales, ya sea en la industria textil, caso de la primera de ellas, como en la mina, caso de la segunda. En ambas producciones se acude a momentos anteriores a los de la Guerra Civil con un ánimo claramente aleccionador acerca de la conflictiva realidad que vino a solventar el golpe militar.

Resumiendo a grandes rasgos el periodo, destaca en primer lugar que, junto a productos de exaltación patriótica o religiosa que caracterizan el periodo, no encontramos ninguna muestra de enaltecimiento del trabajo acorde con los principios falangistas arriba descritos. Sí que existe una clara opción a favor de determinados tipos de trabajo, especialmente el de labrador, frente a otros que ya se intuía serían el futuro del país. Además del principio armonicista presente en la

\footnotetext{
${ }^{24}$ J. González Requena, «Apuntes para una historia de la rural en el cine español», en VV.AA., El campo en el cine español, Filmoteca Española, Madrid, 1997.

${ }^{25}$ De esta época es Forja de Almas (Eusebio Fernández Ardavín, 1943).
} 
empresa, se describen relaciones laborales claramente jerarquizadas presididas por el empresario, que no sólo es el dueño de la empresa, sino también el portavoz de determinados intereses superiores patrios. En este sentido, son especialmente significativas las escenas de despido en El último caballo, donde se describen dos despidos disciplinarios, carentes de garantías y justificados empresarialmente por la falta de identificación de los trabajadores con los objetivos empresariales. Junto a ello, todo el periodo está presidido por un claro afán moralista que condena todas las desviaciones del deber que, como trabajadores, les corresponden teóricamente a aquellos que lo son, muy en la línea de la propia Ley del Contrato de Trabajo de 1944, en cuyo art. 60 se enumeraban como deberes primordiales del trabajador la diligencia en el trabajo y la colaboración en la buena marcha de la producción del comercio o en la prosperidad de la empresa a que pertenece.

Por último, comienzan a aparecer representaciones del hecho laboral que serán reproducidas en la década siguiente y cuyas implicaciones desarrollaremos en su momento. Uno de los casos a los que nos referimos es La honradez de la cerradu$r a$ (Luis Escobar, 1950) ${ }^{26}$. Película adelantada a su época y más propia de la siguiente etapa, nos presenta un mundo del trabajo hostil, que no permite alcanzar una vida digna para los trabajadores, es decir, claramente conectada con representaciones posteriores tales como Esa pareja Feliz (Bardem-Berlanga, 1951). Asimismo, el reflejo de las miserables condiciones de vida de la clase trabajadora, contrastadas en ocasiones con las de las clases superiores, que tan rico reflejo desde distintas perspectivas tendrá en la próxima década, no deja de aflorar a poco que se realice un espigueo del cine de los cuarenta. Este es el caso de Los novios de la noche (Benito Perojo, 1940), adelantado reflejo pre-neorrealista del «miserabilismo» ${ }^{27}$, y que provocó la reacción de las autoridades ${ }^{28}$, de Alma de Dios (Ignacio F. Iquino, 1941), La chica del gato (Ramón Quadreny, 1943) y Barrio (Ladislao Vajda, 1947) $^{29}$. Y es que las extremas condiciones de vida de las clases populares en el primer franquismo generaron el descontento incluso de los que habían contribuido a subvertir el orden constitucional. Todas estas expresiones fílmicas, en una suerte de realismo previo al que será predominante en la década siguiente, reflejan las duras condiciones de vida de una clase trabajadora que había visto sus salarios descender hasta en un $25 \%$ de los que venían percibiendo antes de la Guerra ${ }^{30}$.

Para concluir, hemos de advertir que ya en esta época se aprecia una de las tónicas generales del cine español, esto es, la evasión como objetivo básico de

${ }^{26}$ Véase I. Zumalde Arregi, «La honradez de la cerradura», en J. Pérez Perucha, Antología crítica del cine español, Cátedra-Filmoteca Española, 1997, p. 270.

${ }^{27}$ R. Gubern, Benito Perojo. Pionerismo y supervivencia, Madrid, Filmoteca Española, 1994, p. 321.

${ }^{28}$ J.L. Castro de Paz, Un cinema herido. Los turbios años cuarenta en el cine español, p. 54.

${ }^{29}$ Esta última se trató de explicar, por los críticos próximos al régimen, como una película que, en realidad, no reflejaba a verdaderos tipos españoles (J.L. Castro de Paz, Un cinema herido, p. 165).

${ }^{30}$ S. Ellwood, Historia de Falange Española, Crítica, Barcelona, 2001, p. 141 y 165. 
esta forma artística. Las empresas cinematográficas, debido a la escasa rentabilidad de las películas abiertamente militantes, no terminan de integrarse totalmente en el nuevo ideario político, por lo que los filmes de compromiso con dicha ideología son excepcionales. Es más, dentro de las películas de compromiso se prefiere, por parte de las autoridades, aquellas más planas que las más próximas a la transmisión del genuino discurso falangista ${ }^{31}$, el cual queda desterrado del cine. Predominará claramente, en cambio, un cine de «consolación» ${ }^{32}$, quedando, en buena medida, fuera de las pantallas la ideología franquista ${ }^{33}$. El trabajo y las relaciones de trabajo quedan, pues, limitados al papel de simples comparsas en las manifestaciones de fuerza del propio régimen, o bien a meros elementos decorativos de las inauguraciones de obras públicas a través de las imágenes del NO$\mathrm{DO}^{34}$. En último extremo, detrás de este ocultismo de la clase trabajadora del primer cine después de la Guerra Civil late el temor permanente a esta clase y a su capacidad organizativa, incluso cuando lo hace a través de Falange Española ${ }^{35}$.

\subsection{Continuismo del franquismo. Aparición de las primeras fracturas}

Más de diez años trascurridos desde la victoria del bando fascista y España se encuentra imbuida aún en una grave crisis económica, de vivienda, etc. Algunos de los incondicionales iniciales comienzan a aguzar su ingenio para, dentro de los valores e ideología del franquismo, realizar, al mismo tiempo, críticas más o menos soterradas. La miseria, el hacinamiento, la delincuencia, la prostitución, el estraperlo hacen acto de presencia en el cine español. La manera de reflejarlo, desde los valores de los vencederos o desde la óptica de una discreta oposición, variará, pero no el objeto de la representación.

Por otro lado, pese a la dura represión de los fenómenos organizativos de los trabajadores, la década de los 50 comienza con graves conflictos laborales, especialmente en Vizcaya, Madrid y Barcelona. Los primeros fenómenos huelguísticos significativos hacen acto de presencia en el seno de un Estado que había decretado la eliminación de las clases y sus consiguientes conflictos.

Asimismo, el país comienza a salir del aislamiento al que el régimen de Franco se vio sometido tras la Guerra Mundial. De este modo, la ONU revoca la resolución que recomendaba la retirada de embajadores extranjeros de nuestro país. Se firman los pactos económicos-financieros con EE.UU. y un nuevo Concordato con la Santa Sede.

\footnotetext{
${ }^{31}$ En este sentido, véase el contraste entre Raza (Saenz de Heredia, 1941) y Rojo y Negro (Carlos Arévalo, 1942), descrito por J.L. Castro de Paz, Un cinema herido, p. 37.

${ }^{32}$ R. Gubern, «Los imaginarios del cine del franquismo», en R. Gubern y otros, Un siglo de cine español, Academia de las Artes, Madrid, 1997, p. 164.

33 J.M. Company, Formas y perversiones del compromiso, p. 17-18.

${ }^{34}$ R.R. Tranche y V. Sánchez-Biosa, NO-DO. El tiempo y la memoria, p. 207.

${ }^{35}$ S. Ellwood, Historia de Falange Española, p. 126.
} 
El PCE renuncia a la lucha armada e inicia su oposición no violenta, que nuclearizará buena parte de la disidencia interna. Desde el punto de vista que aquí interesa, aparecen los indicios organizativos en el campo cinematográfico de los sectores vencidos en la Guerra Civil, especialmente de aquellos identificados, de manera más o menos tenue, con los valores ideológicos de la izquierda.

Otra característica especialmente significativa del decenio es el enorme trasvase de población del campo a la ciudad hasta tal punto que cambiará la fisonomía del país ${ }^{36}$. Este hecho provocará una grave crisis de vivienda que tendrá un enorme reflejo en el cine de la época. Es más, la traducción fílmica de los problemas que rodean a la vivienda se convertirá en una de las vías de representación de la clase trabajadora, con títulos como Surcos y El inquilino (Nieves Conde, 1951 y 1958), El pisito (Ferreri, 1958) o El verdugo (Berlanga, 1963) ${ }^{37}$.

Desde la doble óptica que aquí interesa, el franquismo reaccionará para adaptarse a las nuevas circunstancias que le rodean. Por una parte, durante la década ahora analizada finalizará el largo periodo autárquico, destacándose los aspectos relacionados con el siempre presente anticomunismo del régimen y aliándose con EE.UU. En el plano laboral, los fenómenos huelguísticos demuestran la necesidad de arbitrar vías de participación de los trabajadores en la determinación de sus condiciones de trabajo y comienza a aplicarse el Decreto de 18 de agosto de 1947 que regulaba la constitución de los jurados de empresa y la admisión de los convenios colectivos de trabajo en la Ley de 24 de abril de 1958.

En el plano cinematográfico, el periodo se caracterizará por la renovación de los nombres que a partir de entonces ocuparán un lugar destacado en nuestro cine. Asimismo, el surgimiento de planteamientos claramente críticos con el régimen provoca que éste comience a aplicar, en contra de los contenidos de carácter social, todo el aparato de censura ideado en la anterior década y que hasta entonces se había centrado básicamente en los aspectos relacionados con la moral y las buenas costumbres.

El aparentemente monolítico discurrir de la vida de la España de mediados de siglo se topará en esta década con el inicio de una oposición de diversa tendencia ideológica. Esta oposición tendrá también su reflejo en el cine elaborado en la década. En este sentido, cabría diferenciar dos grandes campos de esta oposición: la oposición interna y la de aquellos que, no habiendo participado en la Guerra, mantienen una clara oposición al régimen en el inicio de sus carreras cinematográficas.

\section{A. El desencanto de Falange}

A pesar del cuestionamiento que sobre la traición a los principios de la Falange elabora la historiadora Sheelagh Ellwood, demostrando que en realidad es la propia Falange la que, de la mano del resto de los sectores del franquismo, se va

\footnotetext{
${ }^{36}$ M. Tuñón de Lara, Historia de España, p. 259.

${ }^{37}$ C. Heredero, «España bajo el franquismo: imágenes parásitas y resistencias críticas», pp. 222 y ss.
} 
adaptando a los nuevos tiempos ${ }^{38}$, no es menos cierto que adeptos al bando vencedor comienzan a sentirse desencantados por la aplicación, por parte del régimen franquista, de aquella utopía por la que combatieron. Unido lo anterior a que la década de los cincuenta no comienza con buenos datos económicos y que las condiciones de vida de la clase trabajadora continúan siendo muy duras, estos sectores críticos dentro del régimen comenzarán a explicitar sus desavenencias también a través del cine.

Nos detendremos en este punto en el análisis de Surcos (Nieves Conde, 1951) por ser paradigmática en este sentido. Será ésta la primera muestra de cine que es vista con claro recelo por importantes elementos del régimen, no tanto, como fue habitual hasta entonces, por circunstancias relacionadas con la moralidad, sino por el claro acento social que la misma transmite. La película nos traslada a una realidad contemporánea al momento de su producción, la emigración a las grandes ciudades desde los distintos pueblos de nuestro país. Dicha emigración no se contempla, como en películas coetáneas, con la más mínima bondad. El deterioro moral de los personajes de la misma es radical; todas las estructuras sociales elogiadas por la ideología que sustenta al franquismo se destrozan en mil pedazos. No existe en todo su metraje casi ninguna muestra de solidaridad o comprensión con los problemas del prójimo ${ }^{39}$. $\mathrm{Al}$ final de su recorrido, y cuando la bajada a los infiernos de los modestos campesinos que pretendieron alcanzar mejor vida en la ciudad es total, sólo queda una solución: la vuelta al campo, la vuelta a las raíces del pueblo español.

Esta demoledora crítica no es realizada por la oposición al régimen más o menos de izquierda, que analizaremos en el siguiente apartado. Por el contrario, se trata de conspicuos representantes del bando vencedor los que llevan a cabo tal proyecto. Así, por ejemplo, la historia de la que parte el filme es el fruto del trabajo de destacados falangistas, como Eugenio Montes, Natividad Zaro, Torrente Ballester y el propio Nieves Conde ${ }^{40}$. Asimismo, no deja de ser paradójico que la película obtuviera el reconocimiento de parte de los dirigentes del momento, como demuestra que fuera acogida al crédito sindical y que, en su peculiar enfrentamiento con un producto netamente franquista como Alba de América (Juan de Orduña), saliera victoriosa, aunque ello le supusiera el puesto al director general de cinematografía García Escudero. Además, obtuvo un claro respaldo de importantes órganos informativos de clara tendencia falangista: Arriba, El Alcázar y Primer Plano le dedican elogiosos comentarios. Esta circunstancia sólo es explicable si se la relaciona con el progresivo descontento de amplios sectores de Falange, el cual termina ocasionando la fractura de hecho del antiguo bloque monolítico del partido único sobre todo a partir de 1954-1956 ${ }^{41}$.

\footnotetext{
${ }^{38}$ Historia de Falange, pp. 115 y ss.

${ }^{39}$ Especialmente significativa es la frase que le espetan a los protagonistas en la cola del desempleo y que periódicamente se reproduce en nuestro país: «han venido a quitarnos el trabajo».

${ }^{40}$ Nieves Conde fue miembro de Falange, llegando a ser jefe provincial del partido en Segovia.

${ }^{41}$ S. Ellwood, Historia de Falange, pp. 178 y ss.
} 
En buena medida, el discurrir de la vida de la familia estará presidido por sus esfuerzos de adaptación a un nuevo mundo, el de la ciudad - con su insolidaridad, su aislamiento, las características de los empleos que van consiguiendo-, que es radicalmente diferente al rural y al que no consiguen adaptarse. Es por ello que consideramos que nos encontramos ante un magnífico instrumento de análisis de la situación del trabajo y de la visión crítica que la misma genera en importantes sectores del régimen.

La película comienza con la llegada a la ciudad de la familia al completo, unida en sus valores y mentalidad y con una clara organización jerárquica de la que se desprende un respeto mutuo. A la cabeza de la familia, el padre (José Prada), portador, de alguna manera, de los valores patriarcales del mundo rural español de la época, será la figura en la cual se simbolice el olvido y desprecio de dichos valores, sustituidos por la ambición, el amor al lucro o el vanidoso deseo de ascenso social. No obstante, es él el único capaz de reaccionar, cuando el desastre ya es irreparable, y comprender cuál es la única solución posible: la vuelta atrás, al origen de su propia inocencia perdida, el mundo rural del que procedían. Todo ello ya está implícito en el título inicial de Eugenio Montes:

«Hasta las últimas aldeas llegan las sugestiones de la ciudad convidando a los labradores a desertar del terruño con promesas de fáciles riquezas. Recibiendo de la urbe tentaciones, sin preparación para recibirlas y conducirlas, estos campesinos que han perdido el campo y no han ganado la muy difícil civilización, son árboles sin raíces, astillas de suburbio, que la vida destroza y corrompe».

La primera obsesión de todos los miembros de la familia, tras alojarse en pésimas condiciones subarrendados en una casa de vecinos ${ }^{42}$, consiste en encontrar un primer trabajo que les permita salir del subarriendo de una habitación compartida con una pariente que ya lleva instalada en la ciudad algún tiempo y que se convierte en el espejo de la pérdida de valores a los que están abocados los recién llegados. Esta búsqueda de empleo no es fácil para ninguno. El hermano mayor lo encuentra de camionero al servicio de un mafioso estraperlista, auténtico hilo conductor del filme. La hermana entrará a servir en la casa donde el mismo individuo mantiene a su amante rodeada de lujos. Por el contrario, aquellos que conservan aún la inocencia o el apego a los valores tradicionales no encajarán en el mundo de la ciudad. Ni el padre ni el hermano menor se consolidan en ningún empleo.

La búsqueda de trabajo lleva a la familia, en primer lugar, al Sindicato que gestiona una oficina de empleo ${ }^{43}$. Un funcionario hastiado atiende a una inacabable cola de demandantes. Al describir su experiencia, el padre se define como campesino, lo que lo convierte en objeto de mofa de todos los demás. A partir de este momento, comienza un discurrir paralelo de los dos sectores de la familia.

\footnotetext{
${ }^{42} \mathrm{El}$ autor volverá a tratar el problema de la vivienda en El Inquilino (1958).

${ }^{43}$ Atribuido al sindicato en la Declaración XIII-7 del Fuero del Trabajo de 1938.
} 
Por un lado, los que mejor se adaptan, el hermano mayor y la hermana, que comienzan a prosperar al tiempo que se degradan como personas y abjuran de hecho de sus antiguos valores. Por otro lado, el padre y el hermano menor, inadaptados a consecuencia de conservar su inocencia y su dignidad o bien por ser explotados como meras mercancías sin consideración a sus circunstancias.

Las diferencias en el éxito a la hora de conseguir trabajo van a traer como consecuencia el dominio de aquellos que aportan ingresos frente a los que no lo hacen, que han de someterse ${ }^{44}$. En este sentido, el padre, antigua referencia indiscutida, comienza a ser vilipendiado y desoído por el resto, incluso por su mujer, que lo humilla atribuyéndole las labores domésticas. El menor, incapaz de conservar un empleo, termina huyendo de la casa al no poder soportar el trato vejatorio al que se le somete, y como consecuencia cae en la mendicidad. Mientras, los «triunfadores» van degradándose al tiempo que ascienden en el peculiar estatus ciudadano. Uno, al convertirse en ladrón al servicio de D. Roque, y la hermana al sustituir a la amante del «Charbelain».

Por tanto, el trabajo de la ciudad — al contrario del que supone la unión con el surco, con la tierra y sus habitantes-, es degradante y termina socavando todos los pilares de España. La familia se rompe en mil pedazos: se consiente el amancebamiento, se destruye la jerarquía familiar, se busca exclusivamente el beneficio privado, etcétera. Al mismo tiempo, otro de los pilares de la España tradicional defendida por el sector de Falange que abandera esta película, esto es, la Iglesia, desaparece de la vida de la ciudad. No aparece en Surcos ni un solo sacerdote con un papel mínimamente reseñable, en contraste con otras películas que sobre temas sociales se producen en esta época, como tendremos ocasión de describir. El rezo del rosario - tradición familiar- es ridiculizado por el triunfador hermano mayor que, por otro lado, en ningún caso, se plantea el matrimonio con la mujer con la que comienza a convivir.

Así pues, esta nueva realidad social, fruto del todavía incipiente desarrollismo en la década de los 50, conlleva la degradación y la proletarización, germen del comunismo $^{45}$. Especialmente significativo es el paso por el trabajo industrial del padre de la familia. Manuel encuentra trabajo como peón industrial. El trabajo se describe como embrutecedor, extenuante e imposible para alguien que ha trabajado en el campo de sol a sol. El martillo pilón parece martillear el resto de fuerzas de Manuel hasta que cae desfallecido. El no ser «capaz» de pertenecer al nuevo mundo de la ciudad le tornará a las degradantes labores domésticas que transitoriamente había soslayado.

En cuanto al hermano menor, tras fracasar en sucesivos empleos y abandonar su casa, cae en la mendicidad. Curiosamente, en un momento del metraje, cuando

\footnotetext{
${ }^{44}$ Afirma el hermano mayor ante un reproche de su padre: «yo gano el dinero y hago lo que quiero».

${ }^{45}$ I. Zumalde Arregi, «Surcos», en J. Pérez Perucha (ed.), Antología crítica del cine español, p. 296.
} 
peores son sus condiciones de subsistencia, se destaca la presencia amenazante de una gran chimenea industrial ${ }^{46}$. Es decir, es el desarrollismo, frente al modo tradicional de la economía española, el que aboca a los mejores españoles a caer en la abyección. Sólo aquellos que conservan la inocencia, que no se integran en el mundo de la ciudad por ser itinerantes titiriteros (son ellos los que recogen Manolo, el muchacho desfallecido por inanición), pueden captar la bondad de los excluidos por el nuevo impulso del capitalismo industrial que se estaba imponiendo en España. En definitiva, sólo el trabajo realmente creativo del titiritero o la labor de la tierra pueden conseguir mantener a España fuera de los males del individualismo burgués.

La muerte del hermano mayor y la caída en la prostitución de la hermana hacen adoptar al padre la única solución posible, la única salida digna: la vuelta a la tierra, el retorno al surco ${ }^{47}$. Curiosamente, dicha decisión se adopta en presencia del único sacerdote que hace acto de aparición en la película (aunque sólo lo haga como oficiante del entierro), cuando se trataba sin embargo de un elemento frecuentemente utilizado en el cine falangista como figura mediadora y superadora de los conflictos de clase.

Junto a Surcos, la década de los 50 es también testigo de otros filmes con temática social elaborados por sectores próximos al régimen, pero que poseen tintes bien distintos de los descritos respecto de aquél. Partiendo de postulados estéticos semejantes, no llevan la crítica hasta los niveles concebidos por Surcos. Dentro de estos ejemplos, siguiendo un orden cronológico, podemos citar en primer lugar Día tras día (Antonio del Amo, 1951). En ella ya se contiene buena parte de los elementos temáticos que marcarán a este grupo de directores. Parece que no es posible para ellos obviar la dura situación por la que atraviesa buena parte de las clases populares en nuestro país. Sin embargo, aquí se hace recaer enteramente la responsabilidad de este hecho en el mal aprovechamiento de las posibilidades que se les ofrecen precisamente a quienes la padecen. Se presentan claras dicotomías entre trabajo e indolencia, resaltándose además el carácter redentor del primero ${ }^{48}$. La opción por los rectos valores del trabajo es la única posibilidad de no caer en el mal camino, y, en los momentos de flaqueza, uno de los pilares del régimen, el sacerdote, servirá de guía y apoyo. Así pues, dos aspectos resultan reseñables: por

\footnotetext{
${ }^{46}$ Este es un elemento que connota opresión y amenaza recurrentemente en la historia del cine. Recuérdese la chimenea que domina el estadio de rugby donde «triunfa» el protagonista del Ingenuo salvaje (L. Anderson, 1963).

${ }^{47}$ Un comentario más amplio puede verse en R. Fernández Sirvet, «Influencias del 'neorrealismo' italiano en el cine social de los cincuenta. Surcos como instrumento didáctico para el estudio del régimen franquista», Biblioteca virtual Miguel de Cervantes; y A. Guerra Gómez, «Las heridas abiertas de la paz. Clases y escenarios sociales de la postguerra en Surcos», Historia y comunicación social, VI, 2001, pp. 229-237.

${ }^{48}$ La película comienza precisamente con el siguiente rótulo: «lo que vais a ver es sólo la historia de dos jóvenes - Ernesto y Anselmo-, pero puede ser la de todos los que en esa edad se hallan ante el dilema de elegir un camino en la vida, y ser, o no, hombres de provecho el día de mañana».
} 
un lado, la opción claramente ideológica de tomar a los protagonistas como átomos aislados de toda realidad más amplia, como pudiera ser la clase; por otro, la referencia a la autoridad del orden paterno, en última instancia representada por el dictador, como única salvaguarda del orden social existente ${ }^{49}$. La desviación de este orden social sólo es una excusa para aquellos que no desean ganarse el pan de una manera honrada ${ }^{50}$.

En segundo lugar, Cerca de la ciudad (Luis Lucía, 1952) comparte muchos elementos en común con Surcos. Desde los puramente estéticos - próximos a una suerte de neorrealismo como el entonces en boga en Italia, al que precisamente se hacen referencias expresas en ambas películas ${ }^{51}$-, hasta el claro interés por reflejar el cine como metalenguaje. Sólo es posible que la primera media hora de metraje pasara el filtro de la censura por el papel redentor que la bondad del sacerdote adquiere a continuación. Efectivamente, las condiciones de vida de la clase trabajadora que se hacina en los suburbios de Madrid son descritas con tal crudeza documental que llega a transmitir una desoladora imagen de la situación del país aún en el inicio de la nueva década. Incluso se recogen en los diálogos explícitas comparaciones a tal situación que no dejan en buen lugar el régimen: «querías ser misionero en tierras lejanas y has encontrado la miseria mucho más cerca». Sin embargo, esta situación no ha de significar necesariamente una crítica al régimen político-económico imperante. Por el contrario, la responsabilidad se encuentra en el desconocimiento general de la realidad de los barrios periféricos de las grandes ciudades, lo cual impide que tales circunstancias puedan ser contrarrestadas por medio del ejercicio conveniente de la caridad cristiana por parte de todos aquellos que pueden permitírsela. Además, tal y como se sugiere a través del personaje interpretado por José Isbert, no se debe ser excesivamente duro en las críticas, pues este hecho sería aprovechado en «el extranjero para desacreditar en su conjunto a España». Por tanto, el esfuerzo del párroco lleva a la sensibilización general de los más pudientes, que, en una suerte de caridad nunca cuestionadora del orden social que genera la desigualdad ${ }^{52}$, terminarán por paliar las necesidades más elementales del barrio.

Es decir, no es la crítica al régimen el camino para acabar con una situación de necesidad, sino el trabajo y el despliegue de los valores de la Iglesia católica, con-

${ }^{49}$ J.E. Monterde, «Día tras día», Antología crítica, p. 290.

${ }^{50}$ J. Pérez Perucha, La nueva memoria: historia (s) del cine español (1939-2000), Oleiras, Via Láctea, 2005, p. 101; y C.F. Heredero, «1951-1961: Conformismo y disidencia», en R. Gubern y otros, Un siglo de cine español, p. 140; y, del mismo, Las huellas del tiempo. Cine español. 19511961, Valencia, Filmoteca de la Generalitat, 1993, p. 290

${ }^{51}$ A este respecto, recuérdese el momento en que en Surcos se llega a afirmar, por parte del personaje que encarna una de las «queridas» del potentado Chamberlain, que «no sé qué gusto encuentran en sacar la vida de los desgraciados con lo bonita que es la de los ricos», con considerable carga irónica por parte del director.

${ }^{52}$ Especialmente significativa es la escena en la que un individuo acaudalado, tras leer la noticia de la labor del sacerdote, advierte a su criado que le recuerde que tiene que dar algo para ayudar. 
cebida ésta como baluarte del régimen franquista. $\mathrm{Al}$ margen del orden establecido, sólo tienen cabida la delincuencia y la degradación. En este sentido, las propias recomendaciones de las autoridades censoras son respetadas escrupulosamente por el director: «que al realizar la película se presente a los enemigos del párroco no como obreros, sino como gente ociosa $»^{53}$. Por último, es curioso que entre decenas de niños necesitados no aparezca ni una sola niña, y que la presencia de mujeres esté prácticamente reducida a una, por ende, caricaturescamente representada.

De semejantes urdimbres parte La guerra de Dios (Rafael Gil, 1953) ${ }^{54}$. En esta ocasión, aparece por primera vez la más denostada institución laboral del régimen franquista: la huelga ${ }^{55}$. Como también ocurre en Amanecer en puerta oscura (J.M. Forqué, 1957), esa figura sólo podía aparecer ligada a etapas anteriores de nuestra época. En esta ocasión, la acción se sitúa en el año 1930 en el contexto de la mina asturiana. Los abusos del patrón han provocado una huelga. La Iglesia se encuentra desacreditada por haber tomado opción por aquél. El nuevo cura tratará de solucionar esas dos distorsiones a un tiempo, y actuando como mediador entre patrón y trabajadores conseguirá los dos fines previstos. Es decir, se trata de nuevo de contemplar a la Iglesia como la mediadora ideal para la superación de los conflictos de clase y como baluarte de la doctrina armonicista, buscando unir a los individuos en pos de la consecución de metas comunes y debiendo convencer a cada clase social de que subordine su interés «al general de la Nación», y así lograr «un orden pacífico» basado en «un mutuo apoyo» ${ }^{56}$. No obstante, hay quien ha visto en esta película la presencia de la inquietud de un cierto sector de la Iglesia que reclamaba una revolución social cristiana ${ }^{57}$, aunque ello contrasta con el hecho de que todavía hoy sigue siendo un filme recomendado por la jerarquía eclesiástica para su proyección en cine-forums católicos.

Una clara muestra de la crisis del entramado ideológico del franquismo, al menos en lo que a su reflejo en el cine se refiere, lo constituye la inexistencia, durante estas dos primeras décadas, de ejemplos de desarrollo de la concepción que del trabajo se propugnaba. Esta década ya anuncia la definitiva crisis. Los ejemplos aquí expuestos evidencian, por una parte, duras críticas a la situación que el incipiente desarrollismo está conllevando; por otra, desde las posiciones más complacientes también se desconfía de los postulados teóricos que se explicitaron en los primeros momentos postbélicos. Por el contrario, el trabajo no es visto casi nunca como emancipador ni potenciador de las virtudes humanas, sino

\footnotetext{
${ }^{53}$ C. Torrerio, «Cerca de la ciudad», en Antología crítica, p. 313.

${ }^{54}$ Un análisis más amplio de esta película, como de la anteriormente citada Las aguas bajan negras, puede verse en La Tertulia Cinematográfica/Sala Oscura, La mina en el cine, Asturias, 1999.

${ }_{55} \mathrm{Sin}$ embargo, tal película fue prohibida durante meses, no por esta razón, sino por las quejas el Colegio de Médicos de Madrid, por aparecer un médico sin escrúpulos en la misma ( C.F. Heredero, Las huellas del tiempo, p.64.

${ }^{56}$ A.V. Sempere Navarro, Nacionalsindicalismo y relación de trabajo, cit., p. 52.

${ }^{57}$ C. Arocena Badillos, «Luces y sombras. Los largos años cincuenta», en La nueva memoria, p. 101.
} 
que se contempla como obstáculo o como alienante actividad que nunca otorga los medios necesarios para acceder a niveles de consumo mayores a los del presente. De este modo, se acude a la lotería, los toros, el fútbol, los concursos radiofónicos, etc., como posibles panaceas que posibiliten ascender socialmente y, por ende, abandonar los respectivos trabajos. Esta hipótesis tiene su fiel reflejo en la forma de representación aquí analizada. Este es el caso de Hay un camino a la derecha (Francisco Rovira Beleta, 1953), en el que un hombre cansado de no poder ofrecer a su familia lo suficiente merced a su trabajo decide cometer un atraco. La desviación del justo camino ocasionará, incluso, la muerte de su hijo. Es decir, el trabajo no se contempla como instrumento emancipador, sino como manifestación del orden que hay que cumplir aunque ello conlleve vivir en la miseria material. La línea de búsqueda de mecanismos que posibiliten la promoción social al margen del trabajo será extraordinariamente explotada a partir de este momento.

\section{B. El comienzo de la disidencia}

En lo que aquí interesa, la década de los 50, junto a lo ya descrito, se caracteriza por el nacimiento cinematográfico de una nueva generación de directores, muchos de los cuales, desde posiciones más o menos críticas, tratarán de otorgar al cine español un mayor calado social. En este sentido, no es de extrañar que uno de los famosos diagnósticos elaborados por Bardem en las no menos conocidas Conversaciones de Salamanca celebradas el mes de mayo de 1955, fuera que el cine español era un cine socialmente falso. Independientemente de las polémicas que se han suscitado sobre tal extremo ${ }^{58}$, lo cierto es que denotaba una cierta intención de estos nuevos autores de superar el predominio del cine de pura diversión para dar cabida en su interior a temas que profundicen más en la problemática social, entre ellos, lógicamente, los referidos al mundo del trabajo ${ }^{59}$.

Únase a lo anterior que la censura comienza a preocuparse mucho más intensamente de los aspectos sociales del cine ${ }^{60}$. Asimismo, la disidencia más radical crea, por primera vez tras el enfrentamiento civil, una organización propia a través de la productora UNINCI, próxima al Partido Comunista ${ }^{61}$.

Desde la perspectiva que aquí interesa, esto es, la manera en la que el arte cinematográfico de la década de los 50 refleja el mundo laboral, se advierte el inicio de una bifurcación de las posiciones disidentes con el franquismo. Por un lado, una primera vía, más próxima al gusto popular, donde el humor ocupa un lugar

${ }^{58}$ J. Pérez Perucha, «El cine español de los 50: algunos elementos del paisaje», Tiempos del Cine Español, IV, pp. 12-13.

${ }^{59}$ Cfr. C.F. Heredero, Las huellas del tiempo. Cine español 1951-1961, Ediciones Filmoteca, Valencia, 1993, p. 60.

${ }^{60}$ J.E. Monterde, «Continuismo y disidencia», Historia del cine español, pp. 246 y ss.

${ }^{61}$ J.E. Monterde, «Continuismo y disidencia», Historia del cine español, pp. 260-261. 
destacado (Berlanga, Fernán-Gómez y Ferreri), y, por otro, una segunda que opta por la línea metafórica que elige el drama como vía de expresión, en la línea, pues, de la opción representada en el teatro por Buero Vallejo.

La elección del humor como compensación del dramatismo que la descripción de la vida de la clase trabajadora implicaba, tenía la ventaja de poder sortear con mayor facilidad el control de la censura, cada vez más consciente de los riesgos que esta temática llevaba implícitos. No obstante, se corría con ello el riesgo de frivolizar y minimizar los graves problemas de la vivienda, el desempleo, los salarios de subsistencia, el fuerte poder disciplinario y directivo empresarial, etc. Por otro lado, no sólo está justificada esta opción por cuestiones relacionadas con la censura, sino también por el intento de atraerse a un mayor número de espectadores, deseosos de consumir un cine de puro entretenimiento ${ }^{62}$.

A este respecto, es paradigmático el caso de Fernán-Gómez, muy prolífico en esa década. En las cuatro películas que dirige este valorado autor -El Malvado Carabel (1955), La vida por delante (1958), La vida alrededor (1959) y Sólo para hombres (1960) - , nos encontramos vivamente descritos algunas de las problemáticas mencionadas, y, a pesar de ello, el humor, y, en ocasiones, posicionamientos próximos a los del propio régimen, convierten a éstas en inofensivos artículos de divertimento. Así, por ejemplo, en El Malvado Carabel (con argumento de Wenceslao Fernández Flórez) alguien que es intrínsecamente bueno decide, tras ser despedido por revelar inocentemente secretos de la empresa, convertirse en un delincuente. Tras una desafortunada carrera como ratero es reintegrado al orden social merced al perdón empresarial, eso sí, previa reducción salarial y porque la empresa necesita perentoriamente nuevos trabajadores. De este modo, un despido disciplinario puramente arbitrario y sin ninguna garantía (recuérdense las garantías procedimentales reguladas en los arts. 77 y ss. de la Ley de Contrato de Trabajo de 1944), se convierte en algo cómico como consecuencia de las ocurrencias posteriores del afectado, aunque entre sus efectos esté el pasar necesidades, incluso alimentarias, o no poder vivir dignamente como un adulto. A pesar de lo dicho, también es cierto que, a través de su descripción en esta película, el mundo de la empresa, con las nulas garantías negociadoras de las condiciones de trabajo ${ }^{63}$, se hace, tras las notas cómicas, evidente, llegándose a identificar por parte de la empresa a aquel que pide un aumento de sueldo con «un revolucionario, un promotor de huelgas». Otros elementos ridiculizados, pero que arrancan de una realidad realmente dolorosa, podrían ser la incorporación de aprendices en la empresa sin remuneración o las penosas condiciones de salubridad de las oficinas de la empresa.

\footnotetext{
${ }^{62}$ Es significativo, a este respecto, analizar las películas de mayor permanencia en cartelera, resultando que ninguna de las películas analizadas aquí se encuentra ni tan siquiera entre las primeras veinte películas más vistas (J.E. Monterde, «Continuismo y disidencia», Historia del cine español, p. 262).

${ }^{63}$ En relación a la negociación de condiciones de trabajo, recuérdese que arranca justo de esta década la admisión de los llamados «convenios colectivos sectoriales» a través de la Ley de 24 de abril de 1958 .
} 
La misma línea mantendrá La vida por delante, descripción de las dificultades de la pequeña burguesía universitaria para conseguir un empleo estable y medianamente remunerado. Su valor como documento sociológico es muy significativo. Hay que destacar, en primer lugar, la concepción de los estudios universitarios como claro elemento diferenciador de estas clases medias de la inmensa mayoría de la población fuertemente proletarizada, población que, por cierto, ni tan siquiera se intuye en el metraje de la película. Puede ponerse como botón de muestra el parlamento del personaje representado por Rafaela Aparicio que espeta al protagonista: «ustedes los señoritos estudian de pequeños para no tener que trabajar después». Se trata, pues, de la descripción de una nueva generación de uno de los sectores de la sociedad próximos al régimen ${ }^{64}$, pero que no consigue reproducir su posición social en los nuevos tiempos ${ }^{65}$. El mundo de la empresa es descrito de nuevo como un lugar donde sólo existe la voluntad del dueño del negocio como instrumento regulador, ejercida a través de medios tales como anticipos graciosos o despidos colectivos no justificados. Sin embargo, el humor, las escasas capacidades atribuidas a la pareja protagonista (elemento que desvía considerablemente las críticas sobre el régimen) y, sobre todo, la incoherencia que supone que por muchas dificultades económicas que sufran sigan conservando el servicio doméstico, terminan diluyendo la veracidad de la descripción de la vida de ese sector de la clase trabajadora.

El último ejemplo de Fernán-Gómez que vamos a tratar aquí, Sólo para hombres (basada en una obra de Miguel Mihura), vuelve a reproducir las mismas fórmulas: humor que contrarresta la estrechez de las condiciones de vida, en este caso de los funcionarios públicos, ocasionado por sus bajas remuneraciones, la inestabilidad laboral o la fuerte jerarquía empresarial. Además, en este caso podrían incluso extraerse fuertes críticas, en la línea del oficialismo franquista, al sistema parlamentario y en general al liberalismo: «para divertirnos tenemos la política».

El autor rompe radicalmente con esta línea en, a nuestro parecer, una obra de mucho mayor nivel artístico en el comienzo de la década siguiente ( $E l$ mundo sigue, 1963). En esta obra, se evidencia la dura situación de la clase trabajadora de las grandes ciudades y, en especial, de la mujer de esta clase. En esta obra maestra, que en ocasiones recuerda a Surcos, se contrapone la dispar suerte de dos hermanas que optan por vida moralmente muy distintas. Las diferencias sociales tan marcadas y el pragmatismo de unos trabajadores con escasa conciencia de clase jalonan todo el metraje de la película. Es significativo, a este respecto, cómo la familia de origen de las dos hermanas protagonistas termina aceptando la vida licenciosa de su exitosa hija y, sin embargo, reprocha a la que ha hecho de su dignidad su único patrimonio que se «ponga a servir», aunque ello sea para alimentar a sus cuatro hijos.

\footnotetext{
${ }^{64}$ El protagonista es definido como un chico del SEU.

${ }^{65}$ En este sentido, es significativa la siguiente frase emitida por el personaje representado por Fernán-Gómez: «al buscar trabajo como un señor corriente, descubrí qué perra es la vida».
} 
Estas mismas notas se reproducirán en los filmes insertables en esta opción estética. Especialmente significativo será el filme inaugural del periodo: Esa pareja feliz, del tándem Bardem-Berlanga (1951). Partiendo de las premisas básicas que se reproducirán significativamente con posterioridad, nos encontramos con una joven pareja de clase trabajadora que vive subarrendada (es decir, de nuevo el problema de la vivienda) y que no consigue, merced a los ingresos económicos que les reportan sus trabajos, vivir con una mínima holgura económica. Las posibilidades que le quedan son o la promoción en el trabajo a través de la formación («a la felicidad por la electrónica») o un día de fortuna ofrecido por un programa radiofónico que publicita el jabón Florit. Además, de nuevo se describe la inoperancia de los atajos (en concreto, el robo de película virgen generará el despido del protagonista de su trabajo como electricista en unos estudios cinematográfi$\cos )$. La penuria de esta prototípica pareja se edulcora con un tipo de humor ${ }^{66}$ que después será seña de identidad de uno de los autores. En resumen, se puede advertir en esta película una nula conciencia de clase por parte de los protagonistas, y una descripción de sus vicisitudes puramente individualista y sin intención deliberadamente «mensajista» ${ }^{67}$. La solución final denota un claro conformismo. Los atajos a la felicidad no son posibles por lo que hay que acatar los avatares que nos proporciona el destino ${ }^{68}$. En esta misma línea continuará Berlanga en sus siguientes películas (Plácido - 1960- y El verdugo -1963), donde de manera más o menos directa retratará la escasez de trabajo e ingresos y la dificultad para acceder a una vivienda, pero, creemos, con escaso ánimo de construir una alternativa a dichas situaciones, una vez abandonadas las reminiscencias regeneracionistas de la influencia de Bardem ${ }^{69}$.

En la misma línea expuesta se podría referenciar Atraco a las tres (J.M. Forqué, 1962), destacable junto a El pisito (Marco Ferreri, 1958) por suponer una descripción de la estructura tradicional de la empresa en España. En concreto, en la primera de las películas se describen las consecuencias negativas que para el empleo supone la necesaria adaptación de las estructuras empresariales tradicionales, en este caso del sector bancario, a los nuevos tiempos. De nuevo, se describen como mecanismos de reacción de los trabajadores ante el empeoramiento de

\footnotetext{
${ }^{66}$ C.A. Sambricio, «Esa pareja feliz», Miradas de cine, LX, 2007, p. 1.

${ }^{67}$ J.L. Sánchez Noriega, Historia del cine, Alianza, Madrid, 2002, p. 409; y C. F. Heredero, «España bajo el franquismo: imágenes parásitas y resistencia crítica», en AA.VV., Historia general del cine, Cátedra, Madrid, 1996, p. 224.

${ }^{68}$ En definitiva, creemos que esta renovación formal y temática del cine español no permite augurar un cambio radical respecto a las palabras de García Escudero de principios de la década: «La maravilla que el cine pudo ser se nos ha convertido en este grosero, banal, mecanizado mecanismo para entontecer a esas muchedumbres que una, dos o tres veces por semana, se sepulta en las salas de proyección para absorber con concupiscencia casi pecaminosa el gran estupefaciente que le hará olvidarse por unas horas de lo que es y le arrebatará el tiempo que necesitaría para saber qué debe ser» («Cine y vida moderna», Arriba, 17/03/1950).

${ }^{69}$ R. Gubern, «Esa pareja feliz», en J. Pérez Perucha, Antología crítica, p. 305.
} 
sus condiciones de trabajo instrumentos ajenos a la organización de los propios trabajadores (se supone que también por la imposibilidad de tales representaciones en un cine vigilado por la censura) y se opta por soluciones ajenas, incluso, a lo laboral, como es, en este caso, un atraco. La inviabilidad de esta solución conduce a la conclusión de que la mejor solución es no tocar las cosas de como están.

Uno de los pocos ejemplos de este período en que se produce un reflejo del mundo del trabajo desde una óptica no cómica, y al margen del sector a continuación descrito, lo constituye Amanecer en puerta oscura (J.M. Forqué, 1957), donde sí que se describen con toda su crudeza las duras condiciones de trabajo en la mina y los abusos cometidos por los representantes de la empresa. Evidentemente, el ambiente de lucha representado en la película exigía sacar el mismo de la época en que se rodó y llevar la acción hasta el siglo XIX. De todos modos, la película demuestra que, aun pudiendo llevar razón, los que se rebelan contra la injusticia serán destinatarios de la acción de la Ley, y de esta manera queda contrarrestado el fuerte arranque social debido a la pluma de Alfonso Sastre ${ }^{70}$.

Junto a la vía cómica surge una suerte de regeneracionismo que, si bien instalado en un cierto posibilismo, tratará de afrontar la representación de las circunstancias menos positivas de esta realidad social en dicho periodo. Evidentemente, el más significativo representante de esta tendencia es Juan Antonio Bardem, temprano militante del Partido Comunista (desde 1943), que llevará a cabo en Muerte de un ciclista (1955) todo un manifiesto de esta opción política y artística. Esta película supone, desde la óptica del análisis aquí propuesto, un reproche a aquellos vencedores de la Guerra Civil que viven instalados en una cómoda hipocresía y que son corresponsables de la situación en la que se encuentran los trabajadores en los años anteriores al desarrollismo. A este respecto, es todo un hito de la representación de las diferencias sociales en el franquismo el montaje paralelo que describe, por una parte, la vida de ocio de la alta burguesía y, por otra, la situación de miseria en que la que vive la clase a la que pertenecía el ciclista accidentado. Además, desde nuestro punto de vista, la película nos muestra, con una enorme valentía, cómo en el seno de la clase media no es posible la regeneración. Todo atisbo de toma de conciencia será atajado para preservar la propia supervivencia del régimen, aunque para ello haya que acabar físicamente con los débiles.

Por último, en el filme se describe uno de los pocos momentos de representación fílmica durante todo el franquismo de una acción colectiva de protesta, la cual, aunque se refiera a una simple protesta estudiantil por cuestiones académicas, es fácil relacionarla con las huelgas que proliferaban en determinadas zonas del país de manera prácticamente contemporánea al estreno de la película, así como con la importante agitación universitaria motivada por las medidas aplicadas por el Ministro de Educación Joaquín Ruiz Jiménez destinadas a mantener un férreo control social en el ámbito universitario ${ }^{71}$. En definitiva, se trata ésta de una vía radicalmen-

\footnotetext{
${ }^{70}$ A. Sánchez Vidal, «Amanecer en puerta oscura», en J. Pérez Perucha, Antología crítica, p. 414.

${ }^{71}$ M. Tuñón de Lara, Historia de España, pp. 286 y ss.
} 
te distinta de la anterior y que inaugurará una opción poco continuada en las siguientes décadas, al menos hasta la Transición ${ }^{72}$. Por todo lo dicho, no es de extrañar que la película recibiera la calificación de «extremadamente peligrosa» ${ }^{73}$.

Otro ejemplo de representación realista del momento histórico que atraviesa nuestro país en esta década lo constituye sin duda Mi tío Jacinto (Vajda, 1956), en la que la situación de paro y la consiguiente penuria asolan a un antiguo torero al que se le ofrece una milagrosa segunda oportunidad que no puede ser más desafortunada $^{74}$. Esta obra, junto a títulos como Segundo López, aventurero urbano (Ana Mariscal, 1952) y Fulano y Mengano (Joaquín Romero Merchant, 1956), supondrá una demoledora representación del suburbio degradado, muy alejada de la imagen cómica tan frecuente en el periodo ${ }^{75}$.

Contrastan los escasos ejemplos de un cine social con la tendencia imperante durante esta década en otras artes, especialmente la poesía. Esta década vive la eclosión creativa de una de las más importantes generaciones poéticas de nuestro país, la denominada como poesía social de postguerra, con nombres tan destacados como José Hierro, Ángel González, Leopoldo de Luis, Blas de Otero o Gabriel Celaya ${ }^{76}$. Es decir, que estos autores consiguieron llevar a cabo una obra de fuerte contenido social, sorteando, con mayor o menor fortuna, la censura franquista. Ello evidencia la dificultad adicional de un arte, como el cinematográfico, necesitado para su gestación de fuertes montantes económicos y cuyo producto requiere de complejos sistemas de distribución.

Hasta aquí dos largas décadas de dictadura, y el resultado de la representación del mundo del trabajo no es nada halagüeño. Si advertíamos de que en la década de los cuarenta no existía una clara representación fílmica del trabajo desde los valores del régimen, la década de los cincuenta evidencia aún más esta falta. Así, cuando el director pertenece al sector ideológico de los vencedores, la descripción se convierte en una crítica más o menos velada a la traición de los valores falangistas que el franquismo supuso. Por otro lado, la censura o el propio desinterés lleva a que los sectores más críticos que surgen en la década de los cincuenta tampoco afronten el tema, limitándose a crear artículos de divertimento con un trasfondo más o menos evidente. Sólo el regeneracionismo representado por Bardem parece vislumbrar una nueva línea en este sentido.

\footnotetext{
${ }^{72}$ Otros filmes del autor durante la década, en una línea semejante, serán La venganza (1957) y, especialmente, Cómicos (1953).

${ }^{73}$ Véase «El cine de Juan Antonio Bardem y la censura franquista (1951-1963): las contradicciones de la represión cinematográfica» (www.cervantesvirtual.com).

${ }^{74}$ Otras películas del periodo con temática relacionada con el mundo del trabajo o de la clase trabajadora son María, matrícula de Bilbao (Vajda, 1960), Cerca de las estrellas (C. Fernández Ardavín, 1961) y Mi calle (Edgar Neville, 1960).

75 J.L. Castro de Paz y J.J. Pena Pérez, Cine español. Otro trayecto histórico (Nuevos puntos de vista. Una aproximación sintética), Ediciones de la Filmoteca, Valencia, 2005, p. 42.

${ }^{76}$ Más ampliamente, Leopoldo de Luis (antólogo), Poesía social española contemporánea, Biblioteca Nueva, Madrid, 2000.
} 
Puede concluirse que, desde el punto de vista ideológico, durante esta década se produce el tránsito del nacional-sindicalismo al nacional-catolicismo. Simbolizado en escena por la sustitución del uniforme de la Legión por la sotana del protagonista de Balarrasa (Nieves Conde, 1950), tiene una de sus mejores representaciones en la permanente presencia del elemento clerical en aquellas películas que reflejan el mundo del trabajo y donde desempeña el difícil trabajo de limar las luchas sociales ${ }^{77}$.

\subsection{El nuevo cine español y la representación fílmica del trabajo}

La década de los 60 significará para nuestro país una suerte de «milagro». El sector industrial supera por primera vez al agrícola, el número de emigrantes sobrepasa el millón y los turistas del año 1965 son ya 14 millones. La renta media aumenta y se produce un considerable incremento del consumo entre las capas medias de la sociedad. Desde el punto de vista laboral, la década comienza con importantes huelgas en las zonas más industrializadas del país (Cataluña, País Vasco, Madrid y Asturias) que se generalizan y extienden al campo andaluz y a las zonas mineras. Los trabajadores dan un paso cualitativo en la conciencia de su capacidad de organización y se movilizan no sólo por mejorar sus condiciones de trabajo, sino también contra las estructuras sindicales del franquismo. Éste responde con una brutal represión contra los dirigentes de las más significativas organizaciones clandestinas. Los intelectuales, incluso algunos antiguos hombres del régimen como Camilo José Cela, Torrente Ballester o Dionisio Ridruejo, protestan por al cariz represivo de los acontecimientos.

Desde el punto de vista estrictamente organizativo, las huelgas de 1962 extienden de manera definitiva a Comisiones Obreras por todo el país, que llegaría a su máxima expresión en las elecciones a enlaces de 1966, donde se superaron todas las previsiones del sindicato con un triunfo total ${ }^{78}$. Es decir, CC.OO., a través de la estrategia del «entrismo», había conseguido subvertir las propias y deficitarias estructuras participativas ideadas por el régimen para el control de los trabajadores en sus centros de trabajo.

Todas estas circunstancias desembocaron en un considerable incremento de la represión del régimen, sobre todo a partir de 1967, cuando las cárceles se llenan de presos políticos. Además, el régimen responde con iniciativas legislativas específicamente laborales, como la Ley sobre derechos políticos, profesionales y de trabajo de la mujer de 1961, los Decretos de salarios mínimos profesionales de 1963 o la modificación de la estructura del sindicato vertical a través de la Ley Orgánica del Estado de 1967.

En definitiva, el periodo que nos proponemos analizar es el más activo de toda la dictadura en lo que se refiere a la vida laboral y sindical. En buena lógica, el

${ }^{77}$ Cfr. C.F. Heredero, Las huellas del tiempo, cit., pp. 192 y ss.

${ }^{78}$ M. Tuñón de Lara, Historia de España, Labor, Barcelona, Tomo 10*, pp. 364 y ss. 
reflejo de todas estas realidades debería abrirse paso en la representación cinematográfica, sobre todo si tenemos en cuenta la radical transformación del plantel de directores en lo que se dio en llamar Nuevo Cine español y Escuela de Barcelona. Sin embargo, sin perjuicio de su posterior profundización, se puede adelantar que este nuevo cine vivirá de espaldas a la realidad social que le circunda, siendo muy escasos los ejemplos de representación del hecho laboral en este periodo, lo que produce un significativo declive del realismo de las anteriores décadas ${ }^{79}$. La razón fundamental pudiera ser una combinación de posibilismo con el hecho de que esta Nueva ola a la española esté fomentada desde la propia administración franquista del cine y, en concreto, en la apuesta personal de su Director general García Escudero $^{80}$. En definitiva, el periodo dio lugar a un cine de cierta calidad, capaz de competir en los festivales internacionales, pero caracterizado por un fuerte escapismo $^{81}$. Ello, evidentemente, no significa que no podamos extraer interesantes ejemplos factibles de incardinar en nuestro objetivo de comprobar la forma en que el cine durante la dictadura representó el mundo del trabajo.

En primer lugar, habría de citarse, como película fundacional a este respecto, Los golfos (Carlos Saura, 1959), que, aunque dirigida aún vigente el anterior decenio, pertenece por derecho propio a esta nueva etapa, situándose su estreno además en 1961. En ella aparecen personajes tipo que ya nos son conocidos en nuestro estudio diacrónico del cine durante el franquismo. Se trata, en este caso, de jóvenes sin muchas posibilidades de ascenso social, lastrados por el desempleo y que hacen presagiar a los grupos de jóvenes marginales, que terminarán en la droga, en prisión, o en ambas, sólo una década después. Sobresale en la película la consideración que tendrá el trabajo, concebido como un obstáculo para el cumplimiento del verdadero deseo de los protagonistas, esto es, que uno de ellos se convierta en torero. De nuevo, el mundo de los toros se convierte en válvula de escape para las penosas condiciones de vida de parte de la población española, que ve el auge del consumismo que depara el desarrollismo, nunca mejor dicho, desde la barrera ${ }^{82}$.

Este mismo llegar a más por vías ajenas al trabajo será argumento recurrente en las películas realizadas por los nuevos realizadores. En ocasiones el intento se produce a través del robo, dado que los protagonistas han sido previamente des-

${ }^{79}$ S. Zunzunegui, «Llegar a más: el cine español entre 1962-1971», en J. Pérez Perucha, La nueva memoria, pp. 143 y ss.

${ }^{80}$ J.L. Castro de Paz y J.J. Pena Pérez, Cine español. Otro trayecto histórico, p. 51; y C. Torreiro, «Una dictadura liberal: 1962-1969», en R. Gubern y otros, Historia del cine español, p. 298 y ss.

${ }^{81}$ Respecto a este escapismo elitista en la Escuela de Barcelona, cfr. C. Torreiro, «Entre la espera y el fracaso: nuevo(s) cine(s) en la España de los 60», en AA.VV., Un siglo de cine español, p. 160.

82 J.E. Monterde, «Los golfos», en Antología crítica del cine, cit., p. 481. También serán los toros el horizonte de superación elegido por El espontáneo (Jorge Grau, 1963). Véase, respecto de esta última, J.L. Sánchez Noriega, Desde que los Lumière filmaron a los obreros, Nossa y Jara, Madrid, 1996. 
pedidos (Llegar a más, J. Fernández Santos -1963) ${ }^{83}$. Esta opción es vista por las autoridades censoras como peligrosa, pues puede llevar al espectador a pensar que «en España la vida es extremadamente difícil hasta el punto de tener que escoger entre emigrar o robar». Los personajes aquí descritos se encuentran en una situación parecida a la de la anterior película, esto es, en una «situación de pérdida de identidad respecto a su condición de obreros» ${ }^{84}$. Es ésta, precisamente, la circunstancia que conlleva la imposibilidad de búsqueda de soluciones a la situación de sus protagonistas. En definitiva, «llegar a más» significa, para una gran cantidad de españoles, su deseo de dejar de ser trabajadores e instalarse en el lujo y el consumo que el desarrollismo mostraba en el NO-DO.

Junto a los toros y el fútbol, la década de los sesenta representa el boom del boxeo, deporte propio de las clases trabajadoras más desfavorecidas ${ }^{85}$ y que puede suponer, para aquellos que consiguen triunfar, unos importantes ingresos que les permiten salir de sus barrios marginados. Este es el eje temático de Young Sánchez (Mario Camus, 1963), según el relato corto de Ignacio Aldecoa. No obstante toda la sordidez que el mundo del boxeo acarrea, la opción de aislamiento radical que implica la elección del protagonista de abandonar todo su mundo de amistades, clase y familia ${ }^{86}$ es vista con buenos ojos por el director, que antepone a todo ello el hecho de que dicha elección es manifestación de su libre albedrío ${ }^{87}$. Se aprecia, además, claramente, la opción del propio director, muy propia de estos jóvenes realizadores, que no conciben otra posibilidad que la pura promoción personal, paradójicamente cuando España se veía sujeta a las más importantes movilizaciones obreras de las tres últimas décadas ${ }^{88}$. Es decir, en el cine de esta época asistimos a un afán de «eliminar todas las aristas que podrían contribuir a situar el enfrentamiento entre clases, para poner el acento en la indiferencia de un mundo en el que los roles sociales están predeterminados. Predeterminación que deja sin virtualidad otra escapatoria que no sea una engañosa fuga del ambiente de cada uno». ${ }^{89}$

En definitiva, se trata de reflejar a unos jóvenes de clase obrera, habitantes de los barrios de los suburbios, sin apenas pretensiones sociales y que sólo piensan

${ }^{83}$ J. Fernández Santos, «Retrato de un tiempo angustioso y sombrío», en C. Heredero y J.E. Monterde (ed.), Los «nuevos cines» en España. Ilusiones y desencantos de los años sesenta, Valencia, Filmoteca de Valencia, p. 403.

${ }^{84}$ J.M. Company, «Llegar a más», en Antología crítica, p. 530.

${ }^{85}$ En la misma dirección, serán las motos el pretexto descrito en El último sábado (Pere Balañá, 1965).

${ }^{86}$ S. Zunzunegui, «Young Sánchez», en Antología crítica, p. 551.

${ }^{87}$ Véanse las palabras del director en E. Rodríguez Merchán, «La fisicidad de los sentidos», C. Heredero y J.E. Monterde (ed.), Los «nuevos cines» en España, p. 401.

${ }^{88}$ El cuento de Aldecoa concluye con un perfecto resumen de todo lo que acabamos de exponer: «Tengo que ganar este combate para mi padre y su orgullo. Para mi hermana y su esperanza, para mi madre y su tranquilidad. Tengo que ganar. Entonces sonó la campana y se volvió. Estaban esperándole».

${ }^{89}$ S. Zunzunegui, «El espontáneo», en Antología crítica, p. 556. 
en prosperar individualmente, todo lo cual permite a los autores de tales películas mantenerse, «sin grandes riesgos, en los márgenes protegidos por la nueva política cinematográfica de García Escudero» ${ }^{90}$.

La emigración también tiene su correspondiente reflejo en el cine de esta época. Casi dos décadas han transcurrido desde que Surcos pusiera el dedo en la llaga de una de las más significativas características de los cuarenta años de la dictadura franquista. A pesar de que el éxodo rural a las ciudades continúa, se abren de manera decidida las fronteras de nuestro país para que nuestros trabajadores recalen en Alemania, Suiza, Francia e, incluso, los Países Bálticos. Paradigmática reflexión sobre las consecuencias del desarrollismo en la clase trabajadora y quizás el ejemplo de película de temática laboral más significativo de esta década, lo constituye La piel quemada (J.M. Forn, 1966). Utilizando largos flash back que parten desde el presente de un trabajador andaluz en la Costa Brava, nos desglosa los padecimientos de unos trabajadores que están enfrentándose abiertamente al régimen en el momento del rodaje de la película. Los protagonistas huyen de una realidad laboral andaluza anclada en el siglo XIX, incluida la selección diaria del manijero de la mano de obra necesaria ${ }^{11}$. Ésta fue la circunstancia que les llevó a trasladarse a Cataluña y trabajar en la construcción o en el sector servicios que atiende al lucrativo negocio del turismo. Sin embargo, la llegada de estos trabajadores a su destino no está exenta de dificultades. Igual que vimos en Surcos, los trabajadores ya asentados conciben a los recién venidos como competencia que abarata los salarios (en esta ocasión ya no se les calificará de paletos, sino de charnegos), sin ningún atisbo de solidaridad entre ellos.

En definitiva, ni siquiera cuando se aborda el tema del trabajo desde una perspectiva más social, se hace - suponemos que por imposibilidad real- con elementos que puedan inquietar al régimen. El franquismo ha sido capaz de nuevo de adaptarse a las nuevas circunstancias. Se permite hablar -e incluso ello se favorece $^{92}$ - de la miseria de la clase trabajadora o de las dificultades de los jóvenes de los barrios marginales, siempre, eso sí, que ello no implique optar por vehículos de canalización de estas inquietudes que puedan llegar a ser perjudiciales para la estabilidad del régimen ${ }^{93}$. No obstante, esta posición es analizada por ciertos

${ }^{90}$ J.A. Martínez-Bretón, «El último sábado», en Antología crítica, p. 614.

${ }^{91}$ En palabras de la Delegación de Información y Turismo: «iQué escena tan emocionante la de la contratación de peones y jornaleros en el campo, que nos recuerda la compra de ganado y la amargura de los que no han sido elegidos, que han perdido con ello el jornal!» (E. Riambau, «La piel quemada», en Antología crítica, p. 643).

${ }_{92}$ El propio García Escudero considera que uno de los tres pecados capitales del cine español había sido la ausencia de tratamiento de ciertas problemáticas sociales (Cfr. R. Cueto, «A medias palabras con los ojos abiertos. La temática social en el nuevo cine español», en Heredero y Monterde, Los «nuevos cines» en España, p. 122).

${ }_{93}$ También podríamos citar Brillante porvenir (V. Aranda y R. Gubern -1964) y Jandro (Julio Coll, 1964). Continúan, además, las películas ambientadas en épocas pasadas, como La busca (Angelino Fons, 1966) o el «western» La cólera del viento (Mario Camus, 1970). 
sectores de los especialistas en el cine de la época como una consecuencia ineludible, no tanto de la voluntad de los cineastas, sino de la censura que imperaba ${ }^{94}$.

\subsection{El trabajo en el landismo}

También las subproducciones del cambio de década tocarán el mundo del trabajo, en las que el modelo de humor zafio y estentóreo se impone a cualquier mensaje o reflexión seria del tema que colateralmente tratan. Es decir, el trabajo y sus protagonistas sólo sirven de excusa para el mismo tipo de bromas que tendrían cabida respecto de otros muchos temas, en especial el erótico. Comienza, pues, una curiosa tendencia del cine español y su correspondiente relación con la censura, permitiéndose cada vez películas más atrevidas en el tema sexual pero igualmente vigilantes de la contestación en el plano de lo social. En este sentido, puede citarse Operación secretaria (M. Ozores, 1966), en donde se acoge sin recato una misógina visión de las mujeres, contempladas como objetos sexuales, y concretamente, en este caso, por parte de un jefe hacia su secretaria durante un fin de semana. En la misma dirección, Las que tienen que servir (J.M. Forqué, 1967), de enorme éxito de taquilla (con más de tres millones de espectadores), combina una descripción muy aligerada del trabajo de las empleadas de hogar en las bases norteamericanas con la asunción, por parte de aquéllas, del modo de vida de los oficiales de dichas bases, convertido en espejo en el que habrían de mirarse. El trabajo doméstico, desempeñado por mujeres y presente a lo largo de todo el periodo, se reflejará en Cómo está el servicio (M. Ozores, 1967), de nuevo con un simple ánimo bufo y rondando el desprestigio generalizado de todo un colectivo de trabajadoras. A éstas sólo les queda un papel en la sombra, de apoyo de grandes hombres de negocios, en Las secretarias (P. Lazaga, 1969).

Es decir, los trabajadores son contemplados de forma considerablemente despectiva por parte de un cine que desprecia su capacidad de trabajo y acentúa su incultura, desconsiderándolos en tanto que clase, e incluso como colectivo. Este tipo de producciones alcaza su máxima expresión en Vente a Alemania Pepe (P. Lazaga, 1971). De nuevo, la bufa representación del sempiterno personaje de Landa deja de lado cualquier descripción mínimamente rigurosa de la realidad a la que se refiere. Ciertamente, la degeneración del cine español hacia una comedia de nulo valor artístico es la última etapa de un cine, el franquista, obsesionado por convertirse en un simple vehículo de entretenimiento y que huye de una temática que pudiera ser peligrosa frente a los poderes públicos.

\subsection{Hacia el final del largo túnel: tardofranquismo y transición}

El tardo-franquismo ejerce, contra lo que pudiera pensarse en un régimen que encarrilaba su tramo final, un control férreo respecto a cualquier expresión de

\footnotetext{
${ }^{94}$ R. Cueto, «A medias palabras con los ojos abiertos », p. 126.
} 
disidencia ${ }^{95}$, y la descripción de una clase trabajadora consciente se sigue concibiendo como el primer problema a abatir. Desde el punto de vista cinematográfico, la industria española vive una de sus peores crisis, por lo que no será posible destacar muchas obras en este lugar ${ }^{96}$. No obstante, también es cierto que surgen, dentro de mundo del cine, posturas cada vez más abiertamente beligerantes contra un régimen que duraba demasiado ${ }^{97}$, pero que resultan muy marginales en lo que respecta a su llegada al público; una circunstancia que se ve acrecentada por la desconfianza de los productores ante cualquier filme que no estuviese sujeto a una rentabilidad inmediata de taquilla ${ }^{98}$. El resultado de ello será un enorme vacío temático sobre los acontecimientos sociales más significativos del periodo, por lo que el momento histórico, de enorme conflictividad laboral, no tiene el más mínimo reflejo en el cine de esta época. Es más, ni tan siquiera se alteran los modos predominantes de representación fílmica, por lo que el periodo se ve rodeado de un pobre continuismo 99 .

Evidentemente, el devenir de los acontecimientos (muerte del dictador, legalización de los partidos políticos, elecciones democráticas, etc.) ocasiona una progresiva flexibilización de la mordaza hasta la desaparición de la censura oficial por el Decreto Ley 3071/77, de 11 de noviembre. Sin embargo, tampoco ello condujo hacia una más valiente representación de todos los temas prohibidos hasta entonces. En concreto, cada vez aparecen con más facilidad, y con menos exigencias de guión, desnudos en las películas españolas, mientras que se siguen poniendo enormes obstáculos a la aparición de discursos disidentes. «De cualquier forma, la estructura de la industria española y la debilidad de los circuitos cinematográficos alternativos no daban para producir un cine radical rupturista, que no se plegase a la legitimidad oficial del consenso y la reconciliación» ${ }^{100}$. Se impone, en definitiva, una tendencia posibilista que actuará como una suerte de censura social y que mantendrá, de nuevo, alejados de los cines a la clase trabajadora y sus conflictos $^{101}$. Es decir, a medida que el fuerte control del contenido del cine español

${ }^{95}$ E. Riambau, «El cine español durante la transición (1973-1978): Una asignatura pendiente», en Gubern (coord.), Un siglo de cine español, p. 181.

${ }^{96}$ M. Vidal Estévez, «Jinetes en la tormenta: In memoriam», en Heredero y Riambau, Los «nuevos cines», p. 201.

${ }^{97}$ A este respecto, sería de destacar el manifiesto aprobado en Sitges en octubre de 1967 por un grupo de cineastas, en el que se llegaba a afirmar que «el cine en cualquier país del mundo es la expresión de la clase dirigente», haciéndose necesario, por tanto, ignorar toda forma de censura, produciendo, pues, al margen de la misma.

${ }^{98}$ E. Riambau, «El cine español durante la transición, p. 187.

${ }^{99}$ P. Pérez Rubio y J. Hernández Ruiz, «Esperanzas, compromisos y desencantos. El cine durante la transición española (1973-1983)», en AA.VV., La nueva memoria: historia(s) del cine español, p. 179.

${ }^{100}$ M. Trenzado Romero, Cultura de masas y cambio político: el cine español de la transición, Madrid, Centro de Investigaciones Sociológicas, 1999, p. 89.

${ }^{101}$ J.E. Monterde, «El cine histórico durante la transición política», en Hurtado y Picó (coord.) Escritos sobre el cine español, Valencia, Filmoteca de Valencia, pp. 59 y ss. 
va relajándose, una nueva censura no coercitiva y presidida por el consenso convierte las películas de contenido laboral en excepcionales, aun cuando encontramos filmes tan emblemáticos como Numax presenta (Joaquín Jodrà, 1980) al final del periodo.

Desde el punto de vista jurídico, la década se abre con normas laborales tan destacadas como el Decreto de prohibición de la cesión de trabajadores y de protección del trabajo en contratas (1970), los decretos de empleo de mayores de cuarenta años (1970) y de empleo de trabajadores minusválidos (1970), la Ordenanza general de seguridad e higiene en el trabajo (1971) y el Decreto de ordenación salarial (1973). En el plano sindical, la Ley Sindical (17/02/71) sólo supuso una modernización semántica del sindicalismo del franquismo, pues, en última instancia, los principios del sindicalismo español continúan siendo la unidad, la generalidad, la representatividad, la autonomía institucional o la asociación de empresarios y trabajadores dentro de cada sindicato. Es decir, que tras más de treinta años el franquismo continúa, prácticamente, en la misma posición de partida. Habrá que esperar a la muerte del dictador para que se regule el derecho de asociación sindical (01/04/76), y aunque se continuará haciendo referencia a las antiguas normas sindicales, se reconoce ya el derecho de los trabajadores a constituir asociaciones profesionales. Sin embargo, la asociación sindical no llega hasta 1977 con la aprobación de la Ley de asociación sindical de 1 de abril. El otro derecho colectivo básico, la huelga, no pasará a ser reconocido hasta el RD-Ley de Relaciones de Trabajo 17/77, de 4 de marzo.

La primera de las películas que aquí nos interesan es Españolas en París (Roberto Bodegas, 1971), que narra la vida de tres españolas abocadas a la emigración, aunque en la misma no se pretenda una profundización seria en las causas de la emigración ni en el impacto laboral y económico que tiene aquélla, centrándose exclusivamente en aspectos sentimentales y puramente personales ${ }^{102}$. Es muy sintomático del desinterés que se generaliza en la época a la hora de describir el momento histórico que se vivía en España, optándose generalizadamente por encuadrar las tramas argumentales en un pasado más o menos reciente. En este sentido, podemos citar Pascual Duarte (Ricardo Franco, 1975) y Pim, Pam, Pum, fuego (Pedro Olea, 1975), que contextualizan sus películas en la posguerra civil. Mirada histórica que también se utiliza en Ciutat cremada (Ribas, 1976), Un hombre llamado «Flor de otoño» (Pedro Olea, 1978) y La verdad sobre el caso Savolta (Drove, 1979), enmarcadas en el tránsito del siglo XIX al XX.

Quizá la más curiosa muestra de la representación del mundo del trabajo sea $E l$ puente (J.A. Bardem, 1976). En esta película, partiendo del estereotipo del landismo, se nos describe el discurrir hacia la toma de conciencia de un español medio desmovilizado que sale de puente burlándose de sus compañeros sindicalistas y que, tras diversas vicisitudes que lo enfrentan con el problema de los presos

102 J.L. Sánchez Noriega, Desde que los Lumière filmaron a los obreros, p. 144. 
políticos, la emigración, la situación del campesinado, los excesos de la burguesía, etc., adquiere la conciencia de clase suficiente como para identificarse con la huelga promovida por sus compañeros en la empresa. Este forzado argumento manifiesta el deseo de su realizador de convertir todos los subproductos cinematográficos de la época en instrumentos al servicio de su ideología. Se trata, pues, de un mensaje explícito que es puesto de manifiesto por su autor con las siguientes palabras:

«No más ambigüedades, claves, símbolos, sobreentendidos, aproximaciones. Si Juan decide asumir su verdadera conciencia de clase, tengo que enseñarlo. Y la mejor manera que se me ocurre es viéndole integrarse con sus compañeros en la lucha organizada por la defensa de sus intereses como miembro de la clase trabajadora» ${ }^{103}$

Sin embargo, esta adquisición de la conciencia de clase de la que habla Bardem poco después de su salida de las prisiones franquistas no es vista con tanta nitidez por el resto del cine de la época. Así, por ejemplo, la ausencia de los señores convierte a los criados en sus sustitutos frente a los nuevos miembros del servicio en Los fieles sirvientes (Francesc Betriu, 1980).

Con uñas y dientes (Paulino Viota, 1978) presenta, por su parte, el más cinematográfico de los momentos de lucha de los trabajadores, esto es, la huelga ${ }^{104}$. La propia opción del director por el enfrentamiento directo y la lucha se convierte en un auténtico alegato contra la política de pactos que se estaba imponiendo tras la muerte del dictador. En otras palabras, la misma política de pactos que imposibilitaba, de nuevo, la presencia de la clase trabajadora como protagonista cinematográfica, se convertía en materia de reflexión a través de una película sobre dicha clase. En la película se muestran los métodos violentos utilizados por la patronal para acabar con la huelga, así como la indiferencia ante estos hechos de quien detenta el poder. En última instancia, la clase trabajadora será siempre la perjudicada:

«Era una metáfora transparente de la sustitución del franquismo, corrupto, sin escrúpulos y asesino, por los hombres de la UCD, razonables y demócratas, pero que precisamente justifican con los excesos de aquellos que van a reemplazar las limitaciones más allá de las cuales ellos mismos no desean ir en absoluto» ${ }^{105}$.

Apuntemos, por último, que la película obedece al interés del autor de hacer con aquélla, no una reconstrucción naturalista del gesto o el vocabulario de los obreros, sino de las formas de dominación de clase bajo el capitalismo ${ }^{106}$.

Finalizamos el recorrido diacrónico por el cine español con una de las más importantes películas que sobre el mundo del trabajo se hallan filmado en nuestro

\footnotetext{
${ }^{103}$ Citado en J.L. Castro de Paz, «El puente», en Antología crítica, p. 754.

${ }^{104}$ Véase, M.M. Ruiz Castillo y J. Escribano Gutiérrez, El derecho de huelga y el cine. Escenas del conflicto social, Valencia, Tirant lo Blanch, 2007.

${ }^{105}$ Texto citado en J.E. Monterde, La imagen negada, p. 274.

${ }^{106}$ J.L. Sánchez Noriega, Desde que los Lumière filmaron a los obreros, p. 111.
} 
país: Numax presenta, del ya citado Joaquín Jodrà. Esta película no sólo supone una aproximación al mundo del trabajo, sino que los trabajadores se convierten en ella en protagonistas absolutos, narradores y productores. El director, recogiendo la tradición del cine francés sesentayochista, realiza un filme que se centra en la descripción de la dignidad de un grupo de trabajadores que, ante la circunstancia del cierre de la fábrica para la que trabajan, optan por la autogestión empresarial. En la película se vienen a reflejar las últimas asambleas que se celebran en la empresa y cierra con el rodaje de la fiesta de despedida, «que posibilita una triple clausura: la de Numax-empresa, la de Numax-película y, de manera metonímica, la de las luchas de clase obrera [...]. No debe extrañar por ello que el propio Jodrá definiese este casi invisible largometraje como 'el acta de defunción del movimiento obrero'» ${ }^{107}$. Aun poniendo en cuestión esta última afirmación, sí es cierto que este filme se puede considerar el último en mucho tiempo de nuestra filmografía que aborda temas obreros desde una perspectiva de plena empatía. Es decir, con Numax muere un cine de representación del mundo del trabajo que apenas si había tenido ocasión de nacer.

${ }^{107}$ P. Pérez Rubio y J. Hernández Ruiz, «Esperanzas, compromisos y desencantos, p. 214. 